\title{
Recent Development in the South China Sea and Vietnam's Approaches
}

\author{
Nguyen Huu Quyet \\ Vinh University, Nghe An, Vietnam
}

\begin{abstract}
This paper examines the new developments in the South China Sea (SCS) disputes between Vietnam and China and their causes. A substantial part investigates the approaches Hanoi has adopted to deal with China's potential aggression in the SCS. The first is the "multilateral" approach, which aims to make full use of Association of Southeast Asian Nations (ASEAN) and ASEAN-centric multilateral security dialogues as useful leverage for the creation of a regional Code of Conduct (COC). The second approach involves the strengthening of "self-help" option by forging new developments in defense capabilities, especially naval power, to deter its northern giant from using force in the SCS. The third approach is the combination of two methods - pursuing engagement alongside a stronger defense and using what might therefore be called "defense diplomacy". These three approaches are not exclusive, but mutually reinforcing, and any shift in priority in each of the three options depends on China's revised policy in the SCS.
\end{abstract}

Keywords: China, Association of Southeast Asian Nations (ASEAN), the South China Sea (SCS), approaches

Since 2007, China's unprecedented assertive approach in the South China Sea (SCS) has determined the nature of the disputes. In late 2007, China established the city of Sansha to administer the Paracel and Spratly Islands (and the submerged reef of Macclesfield Bank), which led to Vietnam's strong diplomatic protests and stirred up anti-China riots in Hanoi and Ho Chi Minh City. In 2009, China sent the United Nation (UN) its official map of the SCS, showing the enigmatic "nine-dotted-line" or "U-shaped line" to claim over $80 \%$ of the region as under its "indisputable sovereignty". Immediately, China's provocative action was protested at the diplomatic level by Vietnam, along with the three other Association of Southeast Asian Nations (ASEAN) claimants and even non-claimant Indonesia. In January 2010, China decided to establish local governing bodies in the Paracel Islands and to develop the islands' tourism industry. These actions provoked Hanoi's condemnation as a violation of Vietnamese sovereignty. In addition, senior Chinese officials told high-ranking US visitors that it had put the SCS into its "core national interest" category of non-negotiable territorial claims - along with Taiwan and Tibet. This implied that China was entitled to defend its national interests in the SCS at all costs, including the use of force. Later, China published the "2010-2020 Grand Plan for Construction and Development for the International Tourism Island of Hainan", in which the Paracel and Spratly Islands would be incorporated in an oceanic multi-purpose complex under the management of the province of Hainan, air and sea tourist routes bound for the Paracel Islands would be enhanced, and registration

Corresponding author: Nguyen Huu Quyet, Ph.D., professor, Department of Political Sciences, and Department of Foreign Languages, Vinh University, Vietnam; research fields: political economy and security in East Asia, ASEAN's foreign policy, regionalism. E-mail: quyet_vinhuni@yahoo.com. 
for the right to use uninhabited islands would be encouraged.

Notably, tensions between Vietnam and China are at the highest level as a consequence of China's deployment of its deep sea drilling oil rig HD-981 in Vietnamese waters south of the Paracel Islands. On May 2, 2014, the state-owned China National Offshore Oil Corporation (CNOOC) deployed its HD-981 in the south of the Paracels, which sits near the edge of two blocks 142 and 143 already created by the state-owned PetroVietnam. The reported location of the drilling rig is totally within the exclusive economic zone and continental shelf of Vietnam, about 119 nautical miles $(221 \mathrm{kms})$ from Ly Son Island off the central Vietnamese province of Quang Ngai and 18 nautical miles south of Tri Ton Island of Vietnam's Hoang Sa (Paracel) archipelago. To guard its oil drilling operation and reinforce its territorial claims, China has deployed as many as 80 ships, including seven military vessels, along with an aircraft to the area. In response, Vietnam dispatched 29 ships in an attempt to disrupt the rig's placement and operations. Also, Hanoi has issued a series of ministerial diplomatic notes to the Chinese Foreign Ministry, affirming that the operation of the oil rig and vessels have seriously infringed Vietnam's sovereignty, sovereign right and jurisdiction over the country's Hoang Sa archipelago, exclusive economic zone and continental shelf, and demanding the immediate removal of illegal Chinese activities in Vietnam's sovereignty. Hanoi also launched a diplomatic campaign at the ASEAN Summit meeting on May 11, in Naypyidaw, Myanmar, calling for the ASEAN member states and the international support for its position after the May 7 incident caused by Chinese vessels to ram several Vietnamese ships, leaving six Vietnamese injured.

In recent years, to strengthen the basis for the legal enforcement of its claims, the Chinese authorities have taken a wide range of measures to assert their de facto control over the SCS. First, China conducted occasional military exercises in the disputed area to send deterrent signals to other claimants (Thuy, 2011). The frequency and coordination level of Chinese military exercises have increased in recent years. Second, China intensified pressure on international firms and corporations to withdraw oil and gas exploitation projects from Vietnam, even though their projects were being conducted within the sovereign and jurisdictional rights of the country ${ }^{1}$. Third, China extended its encroachment on Vietnam's continental shelf and deliberately damaged Vietnam's seismic survey ships ${ }^{2}$. Fourth, every year, China imposed its unilateral fishing ban in the SCS for two months, usually in June and July, the peak of the fishing season ${ }^{3}$.

\footnotetext{
${ }^{1}$ In the middle of 2008, Chinese diplomats in the US repeatedly opposed Exxon Mobile and publicly threatened retaliation against the company in mainland China if it continued to cooperate with PetroVietnam in oil and gas exploration and exploitation projects in offshore areas near the central and southern part of Vietnam. Between 2008 and 2010, China frequently protested other exploration activities conducted by international energy companies within Vietnam's Exclusive Economic Zone (EEZ) and continental shelf, such as BP in Block 117, PGS (Norway) in Block 122, Chevron (US) in Block 122, Pogo (US) in Block 124, ONGC (India) in Block 127, Indemisu (Japan) in Block 04-3, CoconoPhilips (US) in Block 133, Pearl Energy (UK) in Block 06-1, Knoc (South Korea) in Block 11-4, and Gazprom (Russia) in Blocks 111 and 113 (data provided by Prof. Nguyen Chu Hoi, General Administrator of Seas and Islands, Ministry of Natural Resources and Environment, Hanoi, July 27, 2012).

2 Notably, on May 26, 2011, three marine surveillance vessels slashed a cable of a seismic survey ship, Binh Minh 02, operated by PetroVietnam at Block 148 about 80 nautical miles off the Vietnamese coast. Again, on June 9, a Chinese fishing boat escorted by Chinese patrol ships cut a seismic survey cable of Binh Minh 02 at Block 136/03 within the 200-nautical-mile continental shelf of Vietnam and more than 622 miles from China's Hainan Island.

${ }^{3}$ In 2006 and 2007, there were a number of press reports of incidents in which Vietnamese fishermen were killed or detained by Chinese patrol vessels and gunboats. From late 2007, Chinese enforcement became more threatening, with a longer, more frequent, and more aggressive patrol operations and more drastic detainment of fishermen. In 2009, Chinese forces repeatedly detained Vietnamese fishing boats near the Paracel Islands and demanded payment of a $\$ 10,000$ fine for the release of the fishermen. In 2010, six further incidents took place, including cases outside the unilateral fishing ban that led to diplomatic protests from Hanoi and increased Vietnamese demonstrations. In recent years, China has deployed a number of renovated warships as patrol vessels to chase, collide with, and sink small Vietnamese and Filipino fishing boats (Do Thanh Hai, "In Retrospect of China's Policy toward South China Sea Disputes since 2007”, International Studies, 24, June 2011, pp. 137-139).
} 


\section{Why China Revised Approach in the SCS}

China has exercised its unprecedented assertive posture on the SCS dispute in recent years. Beijing's changing maritime strategy has caused the apparently high possibilities for potential conflicts, threatening peace, stability, maritime safety, and security in the region.

What then has caused China's aggressive position toward the disputed waters? Six possible explanations account for Beijing's revised approach. First, the lack of a legally binding multilateral mechanism provided room for China's maneuvers. Although China's entrance to the 2002 Declaration of Conduct (DOC) of the Parties in the South China Sea marked a major change in its stance from a bilateral approach to "bi-multilateralism", involving China on the one hand and ASEAN on the other, the DOC only serves as a political document created by all signatories pledging to seek peaceful solutions to disputes and maritime cooperation in order to maintain regional stability in the SCS, without any enforcement mechanisms to sanction violators ${ }^{4}$. This legal vacuum has been instrumental for China in taking unilateral actions in the SCS. Second, thanks to decades of endless economic growth, China has built up its power, economically and militarily, to a level that has made it much more self-confident and assertive in its external behaviors, particularly during and after the global financial crisis ${ }^{5}$. Thus, China's changing posture on the SCS was linked to its overall security and economic development strategies to become a global power. It has been argued that Chinese expansion in the SCS was just a part of its overall expansionist plans, which include "hard expansion" to enlarge its land and maritime territories and "soft expansion" to enhance its influence and presence in all areas considered strategic in terms of natural materials, energy reserves, and geopolitical significance ${ }^{6}$. Third, the increasing role and activities of the People's Liberation Army (PLA) and China's growing nationalism, as well as competition between interest groups (especially law enforcement agencies and energy corporations) exerted a profound influence on China's policy changes on the SCS issue. Fourth, the stabilizing of China-Taiwan relations allowed for the diversion of Chinese priorities, capabilities, and resources to other issues, notably the SCS (Thuy, 2011). Fifth, actions taken by other claimants in response to Beijing's revised posture contributed to China's overreactions ${ }^{7}$. Sixth, Washington's changing strategic focus on East Asia, which led to the development of political and military ties with its allies and ASEAN member states and, thus, to indirect US involvement in the SCS issue, was a catalyst for China's increasingly assertive posture.

\footnotetext{
${ }^{4}$ According to Provision Five of the DOC, "the parties undertake to exercise self-restraint in the conduct of activities that would complicate and escalate disputes and affect peace and stability including, among others, refraining from any action of inhabiting the presently uninhabited islands, reefs, shoals, cays, and other features, and to handle their differences in a constructive manner". However, the declaration does not clarify what kind of activities could be considered to complicate or escalate a dispute. See more details in Tran Truong Thuy, "Recent Developments in the South China Sea: Unconstrained Waves of Tensions", International Studies, 24 (June 2011), pp. 37-38.

5 Ian Storey, "The South China Sea: The Theatre for Emerging Strategic Competition?". Paper presented at Security Environment in the East Asian Seas, Ocean Policy Research Foundation, Tokyo, February 16-17, 2011, p. 2. Available at http://blog.canpan.info/oprf/img/858/dr.storey_presentation.pdf.

${ }^{6}$ Giap Van Duong, "Vietnam 2008: Twelve Major Problems to Solve". Paper presented at the Retrospect Vietnam workshop, p. 13. Available at http://hoithao.viet-studies.info/2009_GVDuong.pdf.

${ }^{7}$ Since late 2007, all SCS disputants have enhanced their infrastructure and boosted propaganda campaigns about their sovereignty and jurisdiction, as well as stepping up patrols and reconnaissance at sea; particularly notable are Taiwan's completion of a runway on the Island of Itu Aba, the visit of former Taiwan leader Chen Shui-bian to the island, and his mention of the "Sansha Initiative" (Spratly Initiative); the Filipino President's signing of a law on a new baseline of the Philippines (RA9522) in 2008 to lay claim to the Spratlys; Malaysia's claims over part of the Spratly Islands by the visit of its Deputy Prime Minister and Defense Minister on 12 August 2008, and that of its Prime Minister to Hoa Lau Island on March 5, 2009; Malaysia and Vietnam's submission of a joint proposal to the UN Commission on the Limits of the Continental Shelf (CLCS) in relation to an area of seabed in the southern SCS located seaward of their EEZ limits on May 6,2009-a week before the deadline of submission designed by the CLCS.
} 


\section{Vietnam's Approaches}

In response to China's potential aggression in the SCS, Hanoi has adopted its approaches. The first is the "multilateral" approach, which aims to make full use of ASEAN and ASEAN-centric multilateral security dialogues as useful leverage for the creation of a regional Code of Conduct (COC) of the Parties in the South China Sea. The second approach involves the strengthening of "self-help" option by forging new developments in defense capabilities, especially naval power, to deter its northern giant from using force in the SCS. The third approach is the combination of two methods - pursuing engagement alongside a stronger defense and using what might therefore be called "defense diplomacy".

\section{Bringing the SCS to Multilateral Security Agendas}

As China's renewed assertiveness in the SCS generated serious concern, the Hanoi leadership calculated that although Vietnam has consistently pursued an accommodating stance to reduce tensions with China and endeavored to seek a peaceful resolution on the basis of international law, the spirit of the DOC, and the Sino-Vietnamese memorandum of mutual understanding on the issue, facts show that bilateral negotiations on this contentious issue would not prevent China's unpredictable and aggressive actions. Thus, making best use of favorable international conditions to cope with this issue and the leverage of the multilateral regional institutions to call on support for Vietnam's position came to the fore on the government agendas. In addition, according to Vietnamese experts on the SCS studies, China's changing posture on the SCS could have offered an opportunity for Vietnam to gain international support because those very Chinese actions could stir up the regional and international communities' concerns about the region's stability and navigational freedom in international waters. Needless to say, Chinese disruption of the balance of power in its favor and other outstanding issues in Sino-US relations, as well as strategic US maritime interests, could have given incentives for Washington to engage in the region's affairs, including the SCS, to curb China's growing power in the region. Japan and India also had problems with China, given its renewed assertiveness in claims over the East China Sea (Diaoyutai in Chinese or Senkaku in Japanese) and over the 4,057 kilometers border China shares with India, especially in Arunachal Pradesh. Tokyo and New Delhi also have vested interests in the vital sea-lane trade routes along the SCS corridors. China's growing assertiveness in the SCS could have thus provoked the Asia-Pacific's major powers to involve themselves in mediation on the issue for the sake of regional stability and for their strategic and maritime interests. ASEAN had also come to demonstrate its increasing relevance in managing traditional security issues within the region, as evidenced by the creation and expansion of the region's multilateral security institutions. All of these factors were relevant for Hanoi in making full use of "favorable external conditions" to multilateralize and internationalize the issue and, eventually, to establish an ASEAN-China regional COC. Besides, domestically, social concerns relating to the surge in nationalist anti-Chinese sentiments had a significant effect on the leaders' more assertive stance on China. For these reasons, Vietnam actively sought opportunities to multilateralize the SCS issue, through the China-ASEAN, intra-ASEAN, and, particularly, ASEAN-centered security arrangements with a view to enmeshing its northern giant within a legally binding mechanism. A case in point is that during Vietnam's chairing of ASEAN in 2010, Hanoi utilized the chance to put the SCS on the agenda of the 17th ASEAN Regional Forum (ARF) and call for the adoption of the DOC implementation toward the COC at the inaugural forum of the ASEAN Defense Ministerial Meeting Plus (ADMM+8). Unsurprisingly, the US and the regional states raised the issue of guaranteeing maritime 
security for all countries surrounding the SCS (Thuy, 2011). This laid a sound ground for Vietnamese leaders to raise its voice on the Shangri-La agendas, calling on the regional and international support for its position regarding Binh Minh 02 incidents in 2011. Most recently, at the 25th ASEAN Summit held in Naypyidaw during May 10-11, 2014, Vietnamese Prime Minister Nguyen Tan Dung took similar action to call on ASEAN's response and support for Vietnam's position and other maritime security issues arising from China's unprecedented assertiveness when Beijing deployed the drilling oil rig in Vietnamese waters south of Paracel Islands. It is likely that Hanoi would launch its diplomatic campaign to put pressure on Beijing in hope of changing its tough stance on the SCS dispute at the multilateral regional security forums, alongside the ASEAN Summit in Myanmar this year.

\section{Developing a Self-Help Approach}

In parallel with its efforts to multilateralize the SCS issue toward the COC as an enmeshment strategy, Hanoi developed its self-help approach — strengthening its defense capabilities - to a new level as a way of deterring its neighbor from using force and to safeguard Vietnam's vital maritime economic interests.

In terms of naval capabilities, in 2009, in his visit to Moscow, Prime Minister Nguyen Tan Dung signed a contract to purchase six Kilo-class submarines totaling about US\$1.8 billion in value, with a view to possessing a modern submarine fleet within a six-year period. Hanoi has taken delivery of the first two submarines from Russia, with the remaining four to be delivered at a rate of two submarines a year or quicker. This means that Vietnam will have the most modern submarine fleet in Southeast Asia in 2015 or 2016. In addition, in 2010, Vietnam ordered two Gepard 3.9-class frigates from the Russian shipbuilder Zelenodolsk. The first frigate, named HQ-011 Dinh Tien Hoang, was delivered in March 2011 ${ }^{8}$, and the second one, named HQ-012 Ly Thai To, was delivered in August 2012. The Vietnam People's Navy has also built many Tarantul-class corvettes, with Russian assistance. In September 2011, the first locally made artillery ship, the TT400TP, was successfully tested ${ }^{9}$. The ship was created to undertake four missions: wipe out enemy battleships, protect the base of the amphibious fleet, protect civilian vessels, and patrolling ${ }^{10}$. This marked a new development in Vietnam's defense industry. At the same time, the construction of a large military harbor at Hai Phong began, intended as the second-largest naval base after Cam Ranh Bay. When completed, this naval harbor will have the capacity to berth 40,000-tonne large warships and 40-60 naval vessels and submarines ${ }^{11}$.

In terms of developing joint naval-air force capabilities, in early 2010, the General Staff of the Vietnam People's Army (VPA) announced the formation of the 954th Naval Air Force Regiment. In 2011, the navy enhanced recruitment and training programs of naval pilots and technical classes at the Naval Academy before sending them to Russia, India, Canada, and France for specialized training ${ }^{12}$. Hanoi also acquired three

\footnotetext{
${ }^{8}$ Later that month, Russia pledged to help Vietnam build the submarine base it needed to house its new Kilos, provide a loan to help buy rescue and auxiliary vessels and planes for Vietnam's navy, and build a ship repair yard. That yard would benefit the Russians, too, because it could service visiting Russian Navy ships.

9 The ship was tested at the wharf of Hong Ha shipbuilding plant - a state factory established in 2007 in the northern city of Hai Phong.

10 "Made-in-Vietnam Battleship Unveiled", Tuoi Tre News. Retrieved from http://www.tuoitrenews.vn/cmlink/tuoitrenews/ politics/made-in-vietnam-battleship-unveiled-1.46601.

${ }_{11}$ Retrieved from http://vietbao.vn/Xa-hoi/Xay-dung-quan-cang-lon-nhat-mien-Bac/40118807/157/.

12 "Xây dựng lực lượng phòng không-không quân hải quân (Quân chủng Hải quân)" [Strengthening air-naval air forces (the Vietnamese Navy)], Vietnam Military History. Retrieved from http://www.vnmilitaryhistory.net/index.php?topic=21347.0.
} 
EADS-CASA C212 Series 400 maritime patrol and surveillance aircraft from Spain in late 2008. In 2010, the aircraft were equipped with the MSS 6000 side-looking airborne radar from the Swedish Space Corporation for general patrol purposes by the Air Force. In late 2012, the Vietnamese Navy purchased two French helicopters, EC-225 Super Pumas, for offshore patrols and search and rescue missions. The Vietnamese Navy also ordered the purchase of six DHC-6 Twin Otter Series 400 aircraft from Viking Air Company of Canada in May 2010, with delivery scheduled to take place between 2012 and $2014^{13}$, to go with seven Kamov Ka 27 helicopters developed by the Russian Navy. It also acquired 20 Sukhoi Su-27 MK and 24 Sukhoi Su-30 MKK2 multirole fighters, as well as other defense weapons, associated services, and support from Russia ${ }^{14}$.

Coastal defense missile forces were elevated to a new height as well. Under Russian supervision, the Vietnamese Navy had already designed and produced its own P-5 Pyatyorka/Shaddock anti-ship missile, with an enhanced range of $550 \mathrm{kms}$. Russia delivered two K-300P Bastion-P coastal defense systems to Vietnam - the only customer of this Russian missile system — with one delivered in 2005 and another in 2011. The Bastion system incorporated the P-800 Oniks/Yakhont supersonic anti-ship missile for the primary use of attacking targets on land and sea. The attack range was declared to be $300 \mathrm{kms}$ and thus for use in protecting a coastline of over $600 \mathrm{kms}^{15}$. According to Vietnam Defense Newspaper, by 2010 Hanoi had acquired 17 3M24E anti-ship missiles worth 767 million rubles from the Tactical Missiles Corporation (KTRV) of Russia, with a further 16 missiles of this type worth 656 million rubles and eight training missiles 3M24EMB worth 72 million rubles to be delivered ${ }^{16}$. According to the KTRV, between 2009 and 2010, Vietnam acquired the tactical Kh-35E anti-ship missile, also known as the Uran-E, which will serve as the main anti-ship missile on surface battleships of the Vietnamese Navy ${ }^{17}$. In September 2012, the National Assembly approved a decree on the establishment of a national "Fishery Control Force" aimed at patrolling, stopping, and responding to foreign fishing boats or vessels that enter into Vietnam's Exclusive Economic Zone (EEZ), continental shelf, and territorial waters. Vietnam also planned to build fisheries administration branches in 28 coastal provinces, each of which will have large and modern ships to undertake search and rescue missions ${ }^{18}$.

It should be noted that in spite of developing its military capability to deter China from using force, Vietnam's leaders understand well that an armed conflict with China would be detrimental to Vietnam's long-held foreign policy goal of maintaining a peaceful and stable external environment conducive to its domestic reforms and developments. Moreover, Hanoi is acutely aware that Vietnam has an asymmetric naval power relationship with its neighbor and that an open armed conflict with it therefore seems unthinkable. This explains the importance that Hanoi's attached to the rule of international law (the 1982 United Nations Convention on the Law of the Sea) and regional norms (the DOC and the procedure of the COC) as a long-term peaceful resolution while calling on China to adhere to the Sino-ASEAN principles of non-use of force or the

\footnotetext{
13 Retrieved from http://avstop.com/news_may_2010/vietnamese_navy_selects_viking_series_400_twin_otter.htm.

14 Retrieved from http://www.defenseindustrydaily.com/vietnam-reportedly-set-to-buy-russian-kilo-class-subs-05396/.

15 "Siêu âm song sát Bastion-BrahMos" (The Bastion-P system), Vietnam Defense Newspaper (online). Retrieved from http:/vietnamdefence.com/Home/ktqs/tongquan/Sieu-am-song-sat-Bastion--BrahMos/201112/51190.vnd.

16 Vietnam Defence Newspaper. Retrieved from http://vietnamdefence.com/Home/tintuc/vietnam/Viet-Nam-mua-ten-lua-chongham-Kh35E/20121/51307.vnd.

${ }_{17}$ Retrieved from http://english.vietnamnet.vn/en/society/18391/russia-hands-over-full-gepard-missile-to-vietnam.html.

18 Retrieved from http://biengioilanhtho.gov.vn/eng/\%E2\%80\%9Cfisherycontrolforcetoprotectnational-nd-7a0f5381.aspx.
} 
threat of force, no first use of force, and self-restraint in disputes ${ }^{19}$.

\section{Promoting "Defense Diplomacy": Engaging and Hedging}

Facing the mature asymmetry with its northern giant while pursuing its long-term goal of maintaining a peaceful and stable external environment, Vietnam has strengthened "defense diplomacy" as an increasingly important part of its security policy. This tactic involves a combination of engagement and a strong hedging behavior.

In terms of engagement, Vietnam's enhanced defense interaction with China was intended to help prevent tensions over the SCS from escalating into conflict, to address other sovereignty-related issues, and to avoid any negative impacts of this contentious issue on bilateral political and economic relations. To that end, bilateral senior level military exchange meetings were held on a regular basis. Even though, territorial disputes flared up, Hanoi and Beijing elevated their relationship to a "comprehensive strategic cooperative partnership" in the middle of 2008. In 2009, the two countries signed a package of three agreements on the demarcation of their 1,300 kilometers land boundary, and in 2010, they held four strategic defense talks, including bilateral negotiations on the settlement of the Spratlys and Paracels issues at the Deputy Defense Minister level ${ }^{20}$. In addition, Hanoi tactically appreciates China's role in regional security affairs, as Deputy Defense Minister Nguyen Chi Vinh in a visit to China in 2012 judiciously praised China's development, acclaimed its role in regional affairs, and called for China to play a role in regional security, expressing Vietnam's wish and belief that "China would not use power to harm any other country or threaten regional and global peace and stability" 21 . The defense diplomacy also helped to maintain a steady warming of bilateral economic relations; trade turnover between the two countries in 2012 and 2013 reached US\$19 billion and approximately US\$50 billion, respectively, making China the single-largest trading partner of Vietnam. It should be noted that unlike the enhanced military-to-military interactions and economic links, reciprocal party-to-party visits have declined significantly since 2009. This suggests that social factors or else the surge in nationalist anti-Chinese sentiments have exerted some pressure on Hanoi's Party leaders' position toward Beijing, thus explaining the downplaying of ideological solidarity.

In parallel with enhanced defense interactions with China, Vietnam strengthened its "defense diplomacy" with all the littoral ASEAN states (as well as Thailand) and, in particular, with all other major powers that had a strategic interest in hedging against potential Chinese aggression. With ASEAN, Vietnam elevated defense relations to a new height. Reciprocal visits by high-level military officials took place with greater regularity between Vietnam and Indonesia, the Philippines, Thailand, Malaysia, and Singapore. Bilateral defense cooperation between Vietnam's Ministry of Defense and that of the other member states has focused on confidence-building measures and coordination to address defense-related issues of common concern, including maritime security.

Of particularly note is the strengthening of Vietnam's defense interactions with the major security partners

\footnotetext{
${ }^{19}$ Nguyen Vu Tung, "Vietnam's Security Challenges: Hanoi's New Approach to National Security and Implications to Defense and Foreign Policies". Paper presented at the Conflicting Claims to the South China Sea conference, Temple University, PA, USA, March 25, 2010, p. 21.

${ }^{20}$ Nguyen Vu Tung, "Vietnam's Security Challenges: Hanoi's New Approach to National Security and Implications to Defense and Foreign Policies". Paper presented at the Conflicting Claims to the South China Sea conference, Temple University, PA, USA, March 25, 2010, p. 21.

21 “Vietnam Reiterates '3-no's' Defence Diplomacy”, Vietnews, August 26, 2010. Retrieved from http://www.dztimes.net/ post/politics/vietnam-reiterates-3-nos-defence-policy.aspx.
} 
of the ASEAN-led ARF: the US, India, Japan, and Russia. High-level military dialogues between Hanoi and Washington were held on a regular basis to enhance cooperation in maritime security and search and rescue operations, as well as to address the legacy of Vietnam War issues and disaster relief. While Washington's support for a multilateral resolution to the SCS was very clear, an increase in visits by US Navy warships to Vietnamese ports contributed to the strong cooperation between both countries. Most notably, in August 2011, the US Military Sealift Command dry cargo/ammunition ship USNS Richard E. Byrd visited Cam Ranh Bay. This marked a historic first visit by a US Navy ship to this strategic port since the end of the Vietnam War ${ }^{22}$. The re-opening of Cam Ranh Bay, which commenced in 2010, for port calls by all foreign navies for logistics service purposes was therefore an apparent part of Hanoi's hedging strategy. In June 2012, in his visit to Vietnam, Leon E. Panetta paid the first-ever visit to the bay by a US Secretary of Defense, which signaled the latest move on both sides to draw closer military ties ${ }^{23}$. India and Russia also expressed strong interest in visiting the bay, and Japan announced a port call by Maritime Self Defense Force (MSDF) vessels, which are welcomed by Hanoi ${ }^{24}$. Vietnam developed its military ties with Japan to a new level under the auspices of a comprehensive strategic partnership, and Japan expressed its support for Vietnam's position on the SCS, to be resolved through peaceful negotiations and based upon international laws, a position that reflected increasing tensions between Japan and China over Senkaku Island ${ }^{25}$. Hanoi strengthened defense relations with New Delhi and Moscow by signing bilateral agreements with both India and Russia in 2009 to boost Vietnam's military science, techniques, and technology; to provide more specialized training courses for Vietnamese officers; to secure relevant equipment to maintain and repair its weapons; and to buy weapons in a major arms procurement package. In a visit to Russia by Vietnam's President Truong Tan Sang from 26 to 31 July 2012, Vietnam hired Russian consultants to direct the construction of new ship-repair facilities in Cam Ranh so as to develop a ship maintenance capacity for foreign naval ships docking at the bay and to assist in the basing of the six submarines that Hanoi expects to take full delivery in 2014.

In short, Vietnam's enhanced "defense diplomacy" with all countries, particularly with the major powers, was not only of strategic significance in hedging against the threat posed by China in the disputed region but also a diplomatic tactic to avoid a strong reaction from Beijing. The reopening of Cam Ranh Bay, which provided "equal access" to all foreign navies, including China, exemplifies this strategy. Vietnam was careful to assuage Chinese concerns, especially about the presence of US Navy warships in the bay, by repeatedly stressing its "3-no's" defense policy: No military alignment or alliance with any power, no military bases allowed for any country on Vietnamese territory, and no reliance upon another country to counter a third party.

\footnotetext{
${ }^{22}$ Cam Ranh Bay was used as one of the largest in-country US military facilities during the Vietnam War (from 1965 to 1973). It is located in Khanh Hoa Province, some 180 miles $(290 \mathrm{~km}$ ) northeast of Ho Chi Minh City. Geopolitically, the Bay is one of the finest deep-water anchorages in Southeast Asia and provides convenient access to the commercially and strategically vital sea lanes that pass through the SCS (the East Sea or Biển Đông of Vietnam).

${ }^{23}$ See more details in "Defense Secretary Leon Panetta Highlights US Ties to Vietnam During Visit", The Washington Post, 4, June 4, 2012. Retrieved from http://www.washingtonpost.com/world/asia_pacific/defense-secretary-leon-panetta-highlights-usties-to-vietnam-during-visit/2012/06/03/gJQAOWcLBV_story.html.

${ }^{24}$ Defense Ministry of Japan, "Japan-Vietnam Defense Ministerial Meeting”. Retrieved from http://www.mod.go.jp/ e/jdf/no20/leaders.html.

25 "PM Supports Closer Ties with Japan", VietnamNet, May 30, 2012. Retrieved from http://english.vietnamnet.vn/en/politics/ 22964/pm-supports-stronger-defense-ties-with-japan.html.
} 


\section{Conclusions}

Since late 2007, Vietnam has increased military modernization, especially of its naval power, and developed its military defense with all the major powers and ASEAN littoral states to serve its Maritime Strategy Toward 2020 program. However, the "China factor" loomed large behind Vietnam's beefing up of its military capabilities and the new stage in military relations. To address China's potential aggression, Vietnam pursued three combinations of four strategies to cope with its aggressive neighbor. The first involved multilateralizing the issue through leverage of ASEAN and the ASEAN-centric multilateral regional security institutions in the hope of reaching an ASEAN-China regional COC to enmesh China. The DOC guideline implementation (especially the ASEAN-China Joint Working Group and Senior Officials Meeting) toward the conclusion of a COC and the building of a united ASEAN political front were important steps that Hanoi had pursued to secure a multilateral approach to peaceful resolution in accordance with international laws and regional norms. In particular, the ARF, ADMM+, and the Shangri-La Dialogue were crucial forms of leverage in multilateralizing and internationalizing the issue. Hanoi successfully used ASEAN's rotating chairmanship in 2010 to realize this endeavor, especially through the 17th ARF and the inaugural ADMM+ forum.

The second approach Vietnam adopted was to develop its own independent defense capabilities to a new height so as to deter China from using force. This focused on the three core forces-navy, joint naval-air command, and coastal defense missile forces. Russia was the principal exporter of major sophisticated arms packages to Vietnam, in particular six submarines. An additional motive for Hanoi's military modernization was the need to contribute to defense and security cooperation in the region at a level commensurate with its recent economic development and national standing on the regional stage.

The third approach involved the strengthening of "defense diplomacy". This primarily meant engaging China while simultaneously adopting stronger hedging behavior. Thus, on the one hand, Vietnam sought to enhance defense interactions with China so as to avoid an open armed conflict given the asymmetric power relations and to prevent any negative impact from the SCS issue on bilateral politico-economic relations. On the other hand, Vietnam sought to enhance its defensive hedge against the potential threat posed by China by engaging in defense diplomacy with all other major powers, principally the US, Japan, India, and Russia, and all the ASEAN littoral states, notably by reopening Cam Ranh Bay to port calls by foreign navies.

\section{References}

Chen, S., \& Feffer, J. (2010). China's military spending: Soft rise or hard threat? Asian Perspective, 33(4), 47-67.

Ciorciari, J. D. (2009). The balance of great power influence in contemporary Southeast Asia. International Relations of the Asia-Pacific, 9(1), 157-196.

Evans, M. (2011). Power and paradox: Asian geopolitics and Sino-American relations in the 21st century. Asian Geopolitics, Winter 2011, 85-113.

Hung Ming-Te, \& Tai-Ting Liu, T. (2011). Sino-US strategic competition in Southeast Asia: China's rise and US foreign policy transformation since 9/11. Political Perspectives, 5(3), 96-119.

Le Thi Thuy Van. (2009). Vietnam's policy responses to the financial crisis. EAI Background Briefs No. 447. Singapore: East Asian Institute, National University of Singapore.

Nghiên cứu Biển Đông. (2011). Đối thoại Shangri-La 10: Quan tâm về an ninh biển (The 10th Shangri-La: Maritime security raises concern). Hanoi: National Publishing House of Politics.

Pham Trung Dung. (2011). Thúc đẩy các hoạt động Ngoại giao quốc phòng góp phần xây dựng và bảo vệ Tổ quốc (Strengthening defense diplomacy activities, contributing to constructing and protecting the fatherland). Tap chi Quan he Quoc Phong (Defense Relations Review), 13(Quarter I), 25-34. 
Storey, I. (2011). The South China Sea: The theatre for emerging strategic competition? Proceedings from Security Environment in the East Asian Seas, Ocean Policy Research Foundation. February 16-17, Tokyo.

Takashi, S. (2012). China's diplomatic offensive: Consequences for regional relations. Nippon, August 23. Retrieved from http://www.nippon.com/en/editor/f00011/

Takashi, S. (2012). The rise of China and its implications for East Asia. In P. J. Katzenstein (Ed.), Sinicization and the rise of China: Civilizational processes beyond east and west. London and New York: Routledge.

Thuy, T. T. (2011). Recent developments in the South China Sea: Unconstrained waves of tensions. International Studies, 24, $17-24$.

Vu Tien Trong. (2012). Đối thoại Shangri-La—Cơ hội tìm kiếm nhận thức chung và thúc đẩy hợp tác an ninh khu vực (The Shangri-La Dialogue - Opportunity for seeking common perception and promoting regional security cooperation). Tap chi Quan he Quoc Phong (Defense Relations Review), 19(Quarter III), 11-17. 